\title{
Notes on Chinese Currency and Romanization
}

The symbol "\$" and the word "dollar" in the text refer to Chinese silver dollars (yinyuan; used before November 1935) and Chinese yuan (known as fabi, or "legal currency"; used after November 1935); the two were roughly equivalent.

The silver-copper exchange rate fluctuated constantly and varied by region. In Shanghai in the early 1930 s the exchange rates were 1 silver dollar to about 300 to 330 coppers, and 1 copper to 10 cash (wen).

Based on the degree of purity, silver dollars were categorized into "big dollars" (dayang) and "small dollars" (xiaoyang). In the early 1930s, 1 small dollar equaled about .76 big dollar. Unless otherwise indicated, dollars quoted in the text were big dollars.

Chinese currency in the 1940 s was unstable and chaotic both in name and in value. In order to avoid confusion, 1940s prices mentioned in the text represent, wherever possible, conversions of the yuan ( $\mathrm{fabi}$ ) according to its value just before the war $(1936-37)$; the main criterion for conversion is the price of rice.

I have used pinyin romanization with a few exceptions for originally romanized street names (such as Nanking Road instead of Nanjing Road) and conventional romanization for people's names (such as $\mathrm{Ah} Q \mathrm{Q}$ instead of $A$ Q). 
